\title{
Nursery production: A tool for assessing vineyard evolution
}

\author{
Maurizio Boselli1, a , Gianfranco Tempesta ${ }^{2}$ and Monica Fiorilo ${ }^{3}$ \\ ${ }^{1}$ Università degli Studi di Verona, Dipartimento di Biotecnologie, Villa Lebrecht, via della Pieve 70, 37029 San Floriano \\ (Province of Verona), Italy \\ 2 Vivaio Enotria, via Campagnole 2, 31050 Cavasagra di Vedelago (Province of Treviso), Italy \\ ${ }^{3}$ Web editor for "De Vulpe et Uva", www. devulpeetuva. com
}

\begin{abstract}
Vine nurserymen operate in the territory with the vinegrowers. They have to be familiar with the working situation, but even more so with current trends; this is in order to allocate the costly investments for fields of mother plants, both scions and rootstocks, that will be required in the next 10-20 years. Forecasts are useful tools for both public and private users.

The work proposed also analyzes the Italian situation as a useful model for understanding the evolution of individual varieties as well as the dynamics of the different vinegrowing basins. It also analyzes the dynamics of the French and European nursery supply.

"In a glass of wine there are the hopes of a year, the teachings of centuries, the hard work of every day" (P. Raviola).
\end{abstract}

\section{Introduction}

\subsection{Culture and wine}

Much of the history of humankind has been written with a vine cane and the grape product itself, wine, has influenced the very essence of civilization.

Viticulture is not compatible with transhumant groups (hunter-gatherers), being anchored to the territory and to the stable settlement of human groups.

In the Standard of $U r$ (2,600 B.C.), a Sumerian figure toasts with a goblet of wine, fruit of the vine that had already been trained from dioecious to hermaphrodite.

In Egypt, frescoes delight with vineyards and goblets that are raised strictly during ceremonies and for a select few (nobles and priests) and lively drawings of the Tomb of Nakht $(1,425$ B.C. $)$ describe the winemaking process in detail.

Orphic rites of the Dionysian cult in Greece established the link between wine, rituality, spiritual salvation and the promise of afterlife in the 6th century B.C.; symbolism that was adopted by the new Christian cult.

The Etruscans (8th century B.C.) left testimony of the good life, holding a patera of wine.

The Roman cult of the God Bacchus could not conceive of a universe without the sacred drink that transmitted the concepts of wellbeing, happiness and gaining favour from the Gods for a good farming year.

Viticulture enthusiasts (Cato the Elder, 160 B.C., Varro, 37 B.C., Virgil, 36 B.C. and Columella, 1st century B.C.) write in detail about vinegrowing and the production of wines all over the Roman Empire (Boselli et al., 2012).

\footnotetext{
a e-mail: maurizio.boselli@univr.it
}

Christianity adopted this drink for rituals, thus defining a universal expansion: churches, monasteries and abbeys were mainly responsible for the distribution.

\subsection{Historical Excursus on the location of varieties and wine types}

Columella and Pliny already recognised the fact that some wines were good because they came from a certain territory, for example Cecubo and Falerno wines.

During the many centuries of the Roman Empire, wine took on a strategic importance. Large quantities entered the Roman ships (naves onerarie) together with other products such as oil and Garum. The Testaccio Hill in Rome, made up of millions of pieces of amphorae, bears witness to this.

The economy generated by this trade and the expansion of vineyards enter into conflict with metropolitan viticulture, so much so that Domitian's Edict (92 A.D.) imposed the compulsory uprooting of half of the nonItalian vineyards.

During the long medieval period, it was the Oradores (clergy) who jealously guarded the maintenance of symbolism and, together with the Belladores (nobility), they owned most of the farming land worked by the third social class, the Laboradores. This model has only been surpassed in Europe in the last century and was repeated in the colonies, where viticulture, imported by religiosity and the sword of the conquistadores, developed. Dried Moscatel de Alejandria grapes were the usual sustenance of the colonizers, the mother variety for most of South American viticulture.

Monasteries spread viticulture with the typical varieties from the original territory, for example, the

This is an Open Access article distributed under the terms of the Creative Commons Attribution License 4.0, which permits unrestricted use, distribution, and reproduction in any medium, provided the original work is properly cited. 
abbeys of Cluny and Citeaux brought Pinot and Chardonnay grapes to vast territories. The former are known today as "Burgunder".

So coming from Burgundy, the link with the territory the variety, (origin of the trio "local, loyal and constant") the basis for the designations of origin ${ }^{1}$.

Viticulture and culture went hand in hand. The first example of this link breaking came in 1453, with the fall of Constantinople, the region of Asia Minor, today's Turkey, and the consequent abandonment of wine-grape vineyards due to Islamic taboo or veto.

More recently, (1966) the same break occurred with the decolonisation of the Maghreb, which saw the disappearance of 400,000 hectares of French-Algerian vineyards.

The unification of the world with exploration and renewed maritime trade favoured new types of wine: fortified wines, such as Port, Jérez and Marsala, or distilled products: brandy and cognac. The mercantilist model was repeated in the new colonies (South Africa, New Zealand and Australia) that do not have a historical heritage and lineage, but are more based on market values, international varieties, brand names or distribution; bases for a different concept of the wine product.

\subsection{Land ownership and Italian vineyards}

The vineyard is the womb of the mother that protects, feeds and confers a centuries-old identity; this is why it surrounds houses, giving rise to models that have remained, with some innovation, until modern day.

The three above-mentioned categories (Oradores, Belladores and Laboradores) were joined in the Middle Ages by a new producing and trading class which originated in the town districts, the Bourgeoisie, which gave rise to the Renaissance.

Much land owned by the nobles and monasteries passed into the hands of the new social class, who gave it to the workers in concession for sharecropping or rent. This evolution of society only marginally affected the south of Italy, which maintained its landowning structure until the recent agricultural reforms.

This is where the current ownership structure originates, which is heavily fragmented, especially in tree farming.

At the 2010 census, the Italian vineyard had on average 1.7 hectares/farm, and only 2.7 farms exceeded 10 hectares, making up $34.6 \%$ of the total surface area, as shown in the tables below.

The already-highlighted generational change favours the abandonment of micro farms, those under one hectare, which are socially but not economically important. They are particularly common in central and southern Italy and a phenomenon partly shared by other winemaking nations, such as France and Spain.

\footnotetext{
${ }^{1}$ The definition of "terroir" (OIV 2010/vines333/2010) supports the concept of designation of origin. The winemaking "terroir" refers to a space where collective knowledge, interaction between identifiable physical and biological environments and vinegrowing practice are developed; giving the products produced in this space distinctive characteristic.
}

Table 1. Number of farms per class of surface area.

\begin{tabular}{|c|c|c|c|c|c|}
\hline \multirow[b]{2}{*}{$\begin{array}{c}\text { Class of } \\
\text { surface } \\
\text { area }\end{array}$} & \multicolumn{5}{|c|}{ NUMBER OF FARMS } \\
\hline & $<1$ ha & $\begin{array}{l}\text { from } 1 \\
\text { to } 5 \text { ha }\end{array}$ & $\begin{array}{c}\text { from } 5 \\
\text { to } 10 \\
\text { ha }\end{array}$ & $>10$ ha & total \\
\hline NORTH & 69.1 & 35.8 & 7.2 & 4.1 & 116.2 \\
\hline CENTRE & 55.4 & 11.4 & 2.1 & 1.9 & 70.8 \\
\hline SOUTH A & 83.6 & 18.6 & 2.2 & 0.8 & 105.2 \\
\hline SOUTH B & 39.0 & 30.3 & 5.6 & 2.8 & 77.7 \\
\hline ITALY & 247.1 & 96.1 & 17.1 & 9.6 & 369.9 \\
\hline
\end{tabular}

NOTE: South B = Apulia and Sicily. South A = other regions in the south

SOURCE: ISTAT

Table 2. Surface area by class.

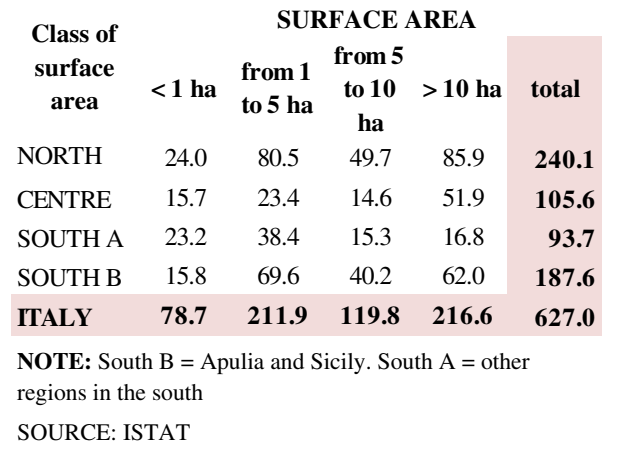

In these three countries that are the driving force behind world viticulture, the social micro farms (the heirs of manorial self-sufficiency) with 533,000 amateur workers, owning 204,000 hectares, will find it difficult to withstand the impact of modernity.

The abandonment of a lot of the wine-farming culture favours that agro-industry able to mobilise new technology, a reduction in costs and outsourcing for bulk wines without territorial identification. They can adapt production to the market and promote lobbies to steer legislation.

\section{Method}

This study analyses what it considers to be the fulcrum of the winemaking system, i.e. the vinegrower and from this it outlines the evolution of the Italian vineyard according to information and data from nurseries.

\subsection{The vinegrower}

The Italian vinegrower has distinctive traits: $97 \%$ farm the land directly and have an average of 1.7 hectares of vineyards, which allows amateur and not professional vinegrowing, so he generally does other jobs.

A high number comes under the category of pensioners and vinegrowing is considered a hedonistic activity.

$93 \%$ of owners have fewer than 5 hectares of vineyards and this fact affects the cultural values, perception, trends and perspectives of viticulture.

Currently there is a clear epistemological break due to secularization, a lack of cultural transmission, identity and generational exchange, leading to an implosion of viticulture seen more as an economic fact. 
Table 3. Farm size: comparison between Italy, France and Spain.

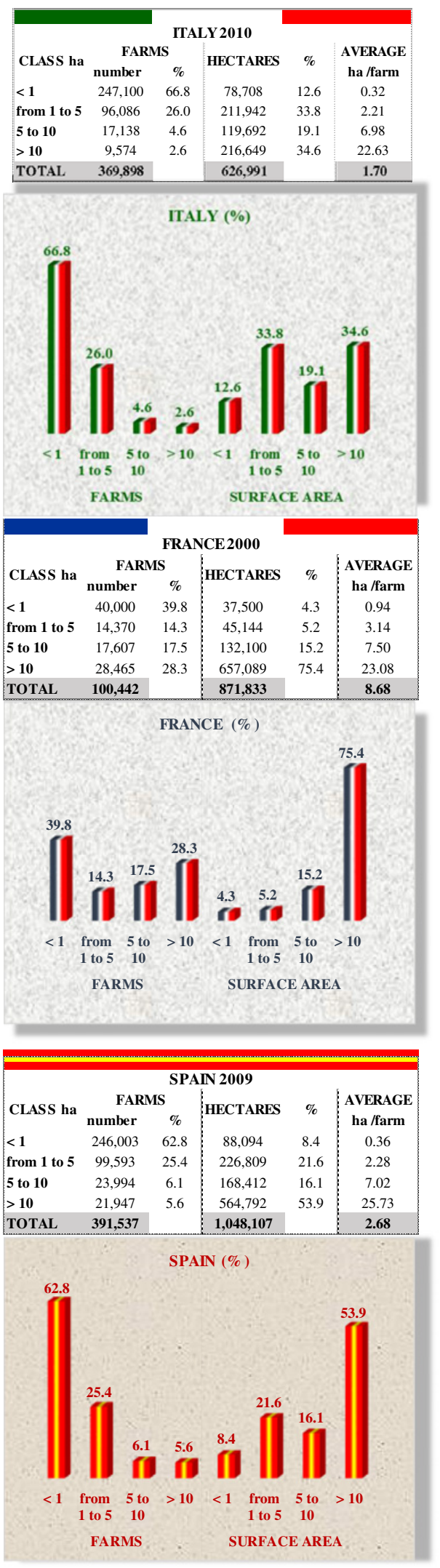

SOURCE: ISTAT, FranceAgriMer, MAGRAM A.

The change in economic and social systems, the great burden of legislation and the economic crisis have reduced the appeal of the winegrowing activity, causing viticulture to be abandoned even more, especially in marginal winegrowing areas. The latter can be identified with amateur vineyards, the heirs of a manorial economy mainly based on native varieties. Hence the reduction of the precious genetic heritage, the erosion of culture and the farming culture.

Further marginality concerns the vineyards whose owners are older and do not have heirs or young people in possession of the right cultural background and willingness to take on the necessary responsibilities for running a vineyard.

More generally, the question is whether the wine culture is able to handle a market that has become internationalised and has alternative drinks such as beers and spirits that allow economic marginality and aggressive trade, or that, conversely, will be conducted with niche products, the prerogative of just a few connoisseurs.

\subsection{The decision-making moment}

He is unlikely to go through official channels, called administrative systemic weedkillers by J. Clavel (2008), which are slow and based on out-of-date information, lacking trend forecasts, while the market becomes ever more agile and aggressive.

The vinegrower knows he must be an "aware player" at the centre of different information and with an in-depth knowledge of informal channels and those in his territory.

Informal channels originate from feedback, the summary of all the information of the production chain and of the decisional need belonging to every businessman.

This new model is set against the official one, described above, that lives on coercive actions (international legislation, plant health limitations, demonization of wine), economic incentives etc.

Much public research is no exception to this plan that is alien to reality. Zoning, for example, often favours political consensus, when viticulture is already organized in welldefined areas favoured by soil, climate and environment.

Vinegrowers live on an "information black market" that fills the void left by officialdom and, which together with their ancestral know-how, determines a collective memory and information that is useful at the time of making decisions.

Spreading news by word of mouth provides information derived from real daily facts; from the in-depth skill of one's own territory; from the cultivation of the vineyard; from the knowledge of one's own varieties; from the behaviour of the plants; in a process of continual feedback with the players (processing cooperatives, bottlers, the market) and everything that gauges the situation.

Figure 1 summarizes how the few cooperative wineries transform most of their grapes into wine, while the producer-wine-makers enhance the value of the territory.

This model of interpreting the decision-making moment is not just an unfounded rumour, esoteric and destabilizing to the system, but a real driving force behind the evolution of viticulture.

The nurseryman "distills and concentrates" all this information, processes it and uses it straightaway to meet the needs of the plants and in the long term, 


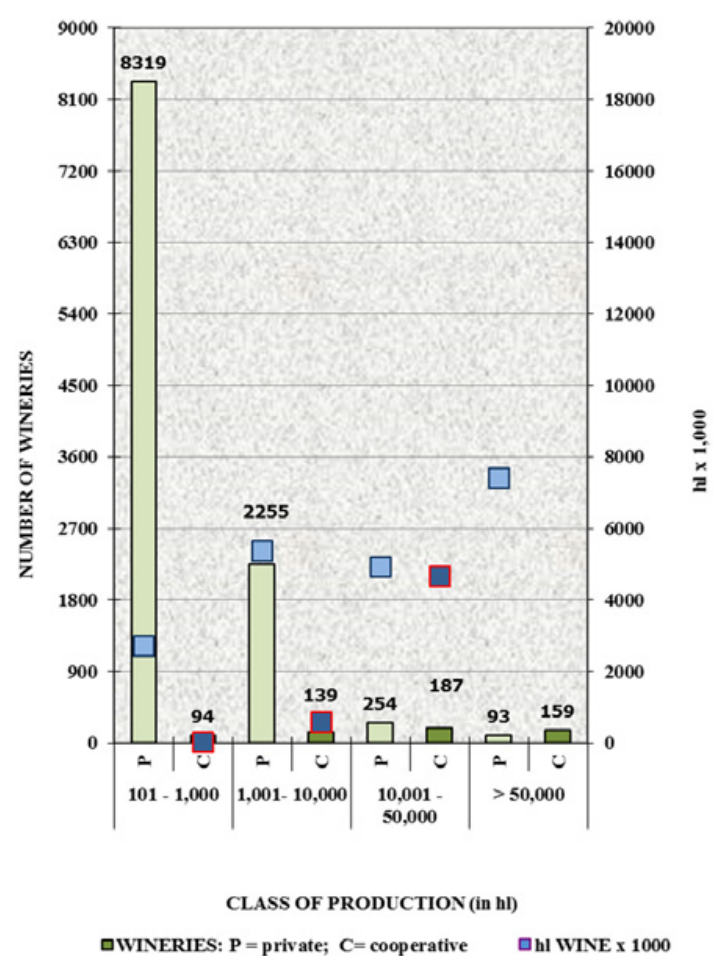

Figure 1. Private and cooperative winemakers by class of production.

to arrange the fields of mother plants useful for 20-30 year cycles.

He holds market dynamics under his thumb, he validates innovations, finely tunes varieties, clones and rootstocks for the future market and suffers important losses for his business.

\section{The Italian vineyard}

\subsection{Origin}

It originates from mixed cropping - from Enotria Tellus, that some authors recognize as "Etruscan viticulture".

Monoculture vineyards (Greek viticulture) were only in Apulia, Sicily (Magna Graecia) and part of Piedmont.

Vineyards were often with several varieties and, sometimes, with dual-purpose varieties (wine and table grapes) destined for local consumption, given the high cost and risk of transport.

Viticulture is currently concentrated and structured in districts, each one with its own identity and a production and market structure (Tempesta et al., 2008; Boselli et al., 2013).

$64.3 \%$ is located in the hills, the remaining $35.7 \%$ on the plains; this latter, the heir of mixed cropping, uses wide training systems with irrigation suitable for high production.

Findings from ISTAT (the Italian National Institute of Statistics) based on the statistical universe, analysed by the authors in the dossier "Vigneto Italia" (Tempesta et al., 2014), give the location and size for each region in $2010^{2}$.

\footnotetext{
2 Can be consulted http://www.devulpeetuva.com/data cap_3_4d.html
}

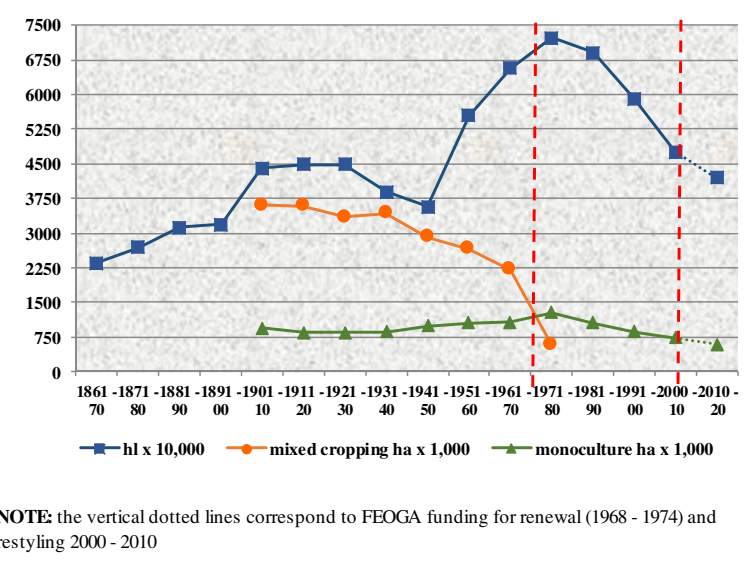

Figure 2. The historical evolution of wine-producing Italy.

Table 4. Consolidated vineyards in districts.

\begin{tabular}{lcc|cc|cc} 
& \multicolumn{2}{c|}{$\mathbf{2 0 \%}$ VINEYARD ON U.A.A. } & \multicolumn{2}{|c}{ TOTAL } & \multicolumn{2}{|c}{ PERCENTAGE } \\
& $\mathbf{2 0 0 0}$ & $\mathbf{2 0 1 0}$ & $\mathbf{2 0 0 0}$ & $\mathbf{2 0 1 0}$ & $\mathbf{2 0 0 0}$ & $\mathbf{2 0 1 0}$ \\
NORTH & 180,038 & 186,851 & 242,623 & 240,793 & 74.2 & 77.6 \\
CENTRE & 65,682 & 59,476 & 122,262 & 106,235 & 53.7 & 56.0 \\
SOUTH A & 36,929 & 37,135 & 115,178 & 94,238 & 32.1 & 39.4 \\
SOUTH B & 161,201 & 154,546 & 195,903 & 186,826 & 82.3 & 82.7 \\
& $\mathbf{4 4 3 , 8 5 0}$ & $\mathbf{4 3 8 , 0 0 8}$ & $\mathbf{6 7 5 , 9 6 6}$ & $\mathbf{6 2 8 , 0 9 2}$ & $\mathbf{6 5 . 7}$ & $\mathbf{6 9 . 7}$
\end{tabular}

NOTE: South B = Apulia and Sicily. South $A=$ other regions in the south SOURCE : IST AT

In brief (Table 4), viticulture is largely consolidated in suitable areas and districts, but there remain vast, weak areas or dedicated to general wines, especially in central and southern Italy.

\subsection{The values of the territory}

The value of the vine-wine is linked to culture and civilization: it is a social marker. When linked to a landscape, the cuisine, the image that visitors get from the territory, the vine-wine gains value. (Boselli et al., 2012).

The place name is intellectual property, expressed by a collective brand.

All of this, interpreted by semiology as "langue"3 (a social convention), gives rise to values that, commercially, are brands.

For some countries langue is a model linked to ancestral rituality, for others, who have planted the tree of liberty on the ashes of Cluny, it is the Goddess of Reason

\footnotetext{
${ }^{3}$ Saussure says that two elements must be identified in language: langue and parole, with very distinct traits. Whereas "langue" is social, passive, external, formal, with few elements and invariant, "parole" is individual, active internally, substantial, with many elements and variable. The concept of langue can be assimilated to that of code. It is a social institution, because, as Durkheim puts it, the individual is coercive and transcendent. A language cannot be controlled by individual people because it assumes a stipulated pact among all the members of a whole society, it is no coincidence that many think language is the most democratic social institution that exists, basing itself on the obvious observation that no natural language has ever been created by contract.
} 


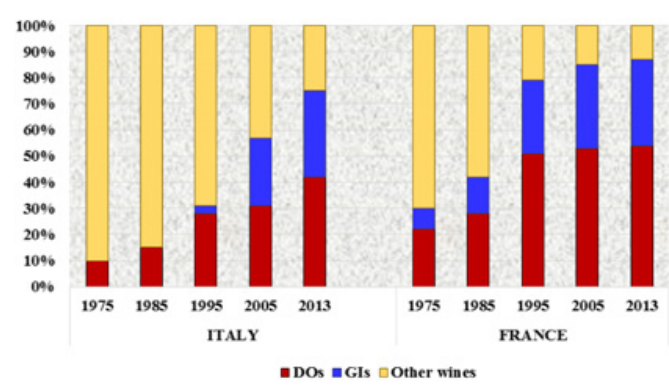

Figure 3. DOs, GIs and other wines.

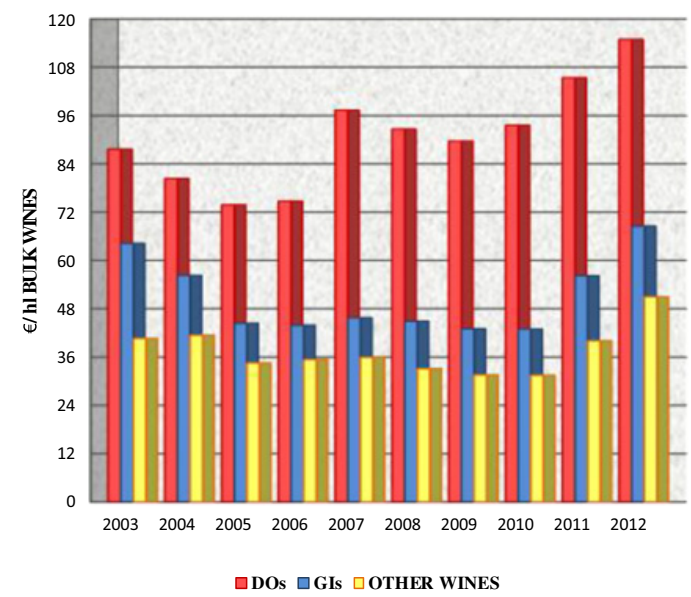

SOURCE: provincial and regional data, from ISMEA and other sources.

Figure 4. Territorial values and segmentation of the wine market in Italy.

and the quality of life, for others still, those used to a kind of Wild West situation, it is a mere commercial value, playing on the name of prestige.

Old World viticulture has consolidated this prestige, called "of the territory" (DO and GI - Designation of Origin and Geographical Indication), as shown in Fig. 3, which compares Italy and France (Tempesta et al., 2007).

It clearly emerges how the DOs and GIs are established later in Italy than in France.

The affirmation of DOs seems to have reached its peak and today it is hindered by the quota of Geographical Indications and varietal wines. ${ }^{4}$

The market is the "final judge" that valorises and assesses the product, giving it what it considers to be its real value. Figure 4 highlights how DOs, GIs and other wines achieve very different prices.

The intervention of mass retail in the wine trade forces a simplification of the supply and favours the latter category (table wines indicating the variety).

This process, together with the ease of world trade, gives bargaining power to the commercial phase.

Despite the affirmation of territorial values, the only defence of the wine sector, the profitability of the sector is suffering, as shown in Fig. 5.

\footnotetext{
${ }^{4}$ The current suitability and advantages acquired by individual areas, as well as the forecast for 2020, can be consulted at http://www. devulpeetuva.com/data_cap_3_5a.html
}

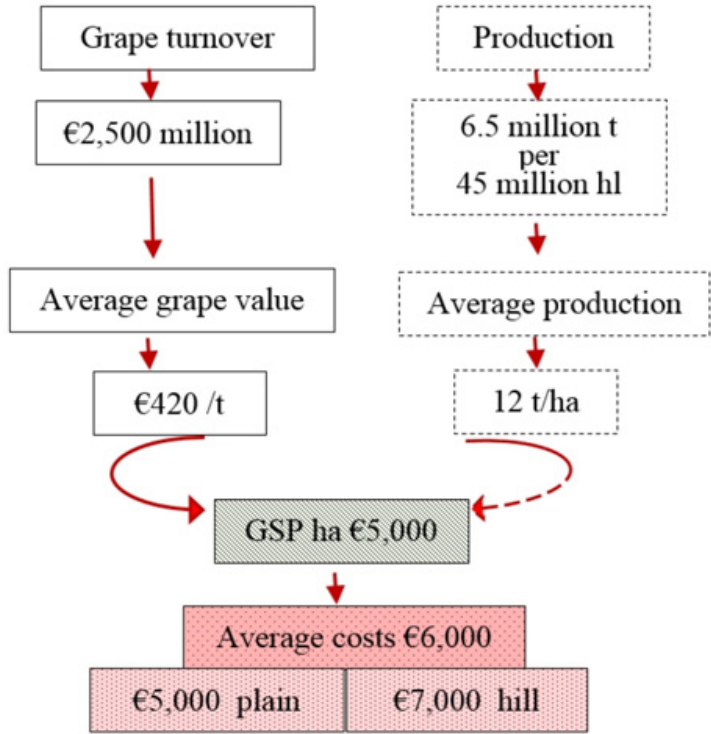

Figure 5. Economic tolerance limits.

Part of the explanation of this "enigma" can be seen in Fig. 1, which shows an overall positive income in the vineyard-cellar-market vertical integration of many small farms.

\subsection{Renewal on its own initiative or subsidized}

The renewal of vineyards is not uniform in the different areas. Some, situated on sloping terrain, are subject to the simple replacement of missing vines, giving rise to perennial vineyards that boast high-quality wines (Boselli et al., 2011).

The remaining hillside vineyards are renewed every thirty years, equal to $3.3 \%$ per year.

Viticulture in the plains, although the proud holder of geographical indications, can and does produce from 15 to 20 tonnes per hectare, making renewal necessary every 25 years, equal to a rate of $4 \%$ per year.

Some plain areas undergo changes of variety, as outlined in more detail below.

High-production areas ( 25 to 35 tonnes per hectare) suitable for general wines, have a forced viticulture and renewal is necessary ever twenty years to keep up the pace. This type of viticulture, little respecting the water footprint ${ }^{5}$, is located in areas where the water factor is not limited by quantity or cost.

Intensive production needs from 4,000 to $5,000 \mathrm{~m}^{3} / \mathrm{ha} /$ year of irrigation water.

The authorities intervene in this physiological renewal with restrictions, legislation and incentives, altering the normal evolutive process and adaptation to the market.

The areas that boast history, as well as cultural, farming and landscape identity and World Heritage sites, remain

\footnotetext{
5 The concept of virtual water, developed by Professor John Anthony Allan from King's College, London, and winner of the Stockholm Water Prize 2008, defines the quantity of water involved in the production and trade of food and other commodities.
} 
Table 5. Theoretical hypothesis for the renewal of Italian vineyards.

\begin{tabular}{|c|c|c|c|c|c|c|}
\hline \multicolumn{2}{|c|}{ TYPE } & \multirow{2}{*}{$\begin{array}{c}\text { ha } \\
60,000\end{array}$} & \multicolumn{4}{|c|}{ RENEWAL } \\
\hline & perennial & & 2.5 & 1,500 & 5,000 & $7,500,000$ \\
\hline & renewed & 260,000 & 3.3 & 8,580 & 4,000 & $34,320,000$ \\
\hline \multirow{2}{*}{ PLAIN } & traditional & 140,000 & 3.3 & 4,620 & 3,000 & $13,860,000$ \\
\hline & forced & 140,000 & 5.0 & 7,000 & 3,000 & $21,000,000$ \\
\hline TOTAL & & 600,000 & & 21,700 & & $76,680,000$ \\
\hline
\end{tabular}

SOURCE: data processed by the authors starting from disaggregated data.

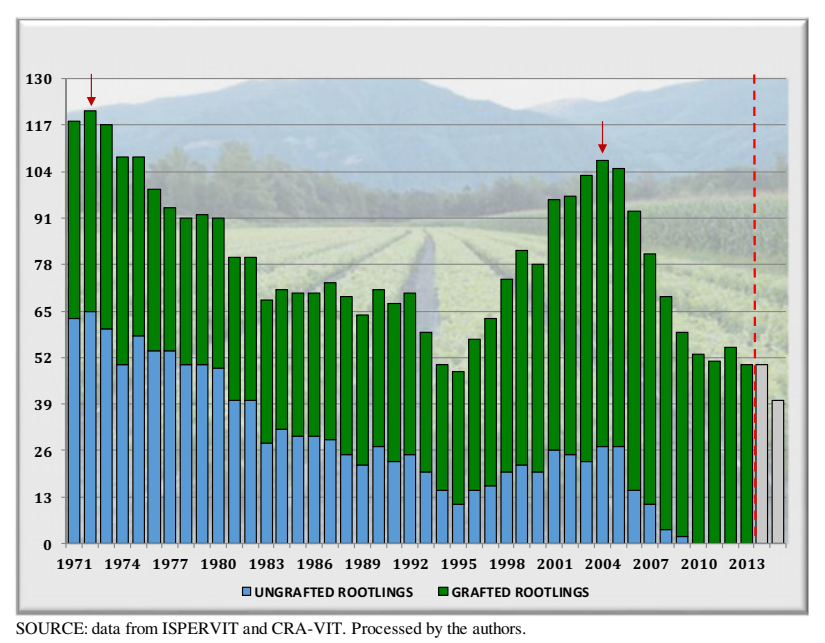

Figure 6. Rootling production and trend (in millions).

anchored to tradition, producing VQPRD wines (Quality Wines Produced in Specified Regions).

For others, the wording "tradition-innovation" is partly modified: for example the changes in variety in the Chianti area.

Other districts undergo significant modifications, with changes in variety and adaptations to the production rules, in order to chase after a market that rewards fruity wines with less tannin and alcohol: welcomed by health enthusiasts.

Ultimately, public intervention has rendered the vineyard mainly coetaneous, mummifying and altering the renewal wording, highlighted in the alternation of nursery production in the last generation (Fig. 6).

Moreover, Italian viticulture has not and does not evolve homogeneously within the territory but, as we have seen, every district has its own identity, commercial character and competitive values: some strong and structured, others collapsing or imploding.

\section{The plant nursery model of viticulture}

The years 2000-2005 coincide with the spontaneous restyling of obsolete and coetaneous vineyards, which were planted with FEOGA (European Agricultural Guidance and Guarantee Fund) contributions in 19701974, and with renewal subsidized by restyling with EU resources.

Despite this strong incentive, the aim of reaching the quota of normal renewal (column "d" of Table 6), was only
Table 6. Restyling of Italian vineyards.

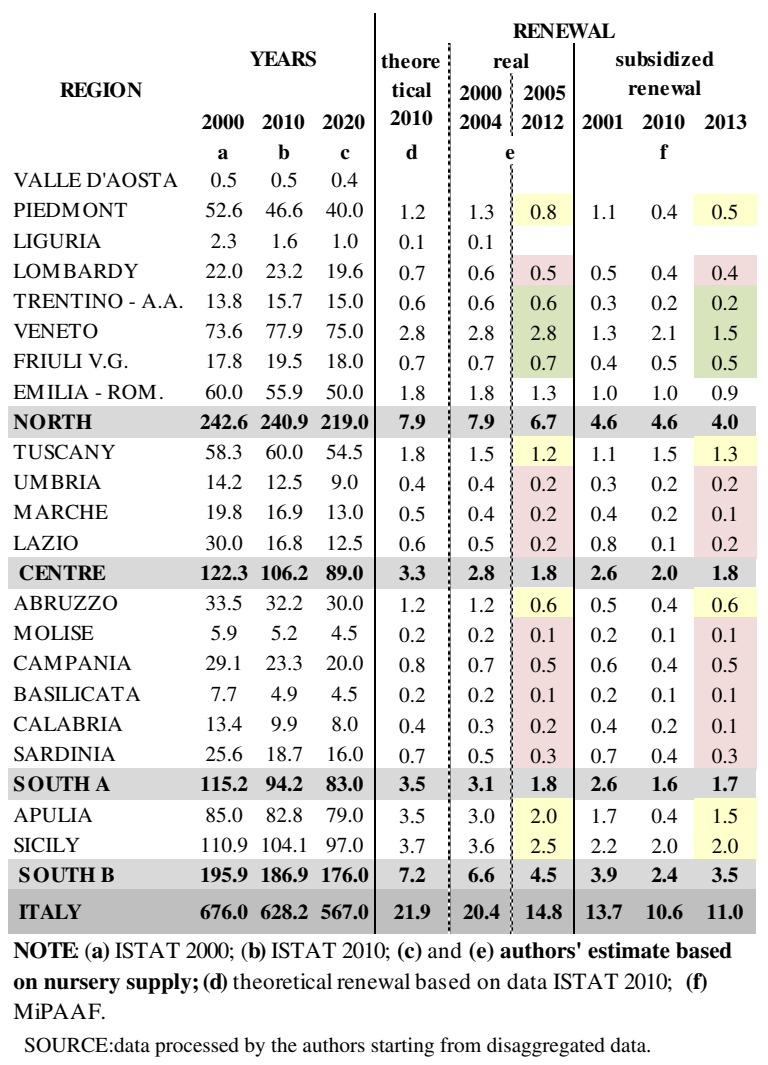

Table 7. Mega trends of Italian Vineyards.

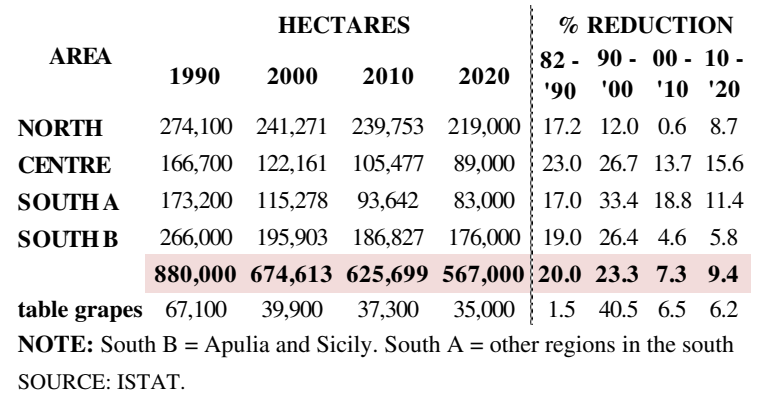

achieved in the regions of Trentino Alto Adige, Veneto and Friuli. For Piedmont, Tuscany, Abruzzo, Apulia and Sicily there is a slight downward trend; the remaining regions have seen viticulture abandoned or imploding.

This leads us to a definition of the evolution of vineyard surface area, area by area, based on nursery supply, conjecturing a size of 567,000 hectares in 2020, no more than 500,000 of which are in production for the market.

\subsection{Varietal evolution}

These parameters are not only mirrored by, but also amplified, in nursery production, inasmuch as the "multiplier" or "pantograph" effect falls on this sector, caused by the above-mentioned coetaneous vineyard.

In this paragraph, by variety we mean a distinct, stable and homogeneous entity as set down by European legislation and not interpretations based on genetic identity (Anderson and Aryal, 2013, Robinson et al., 2012). 


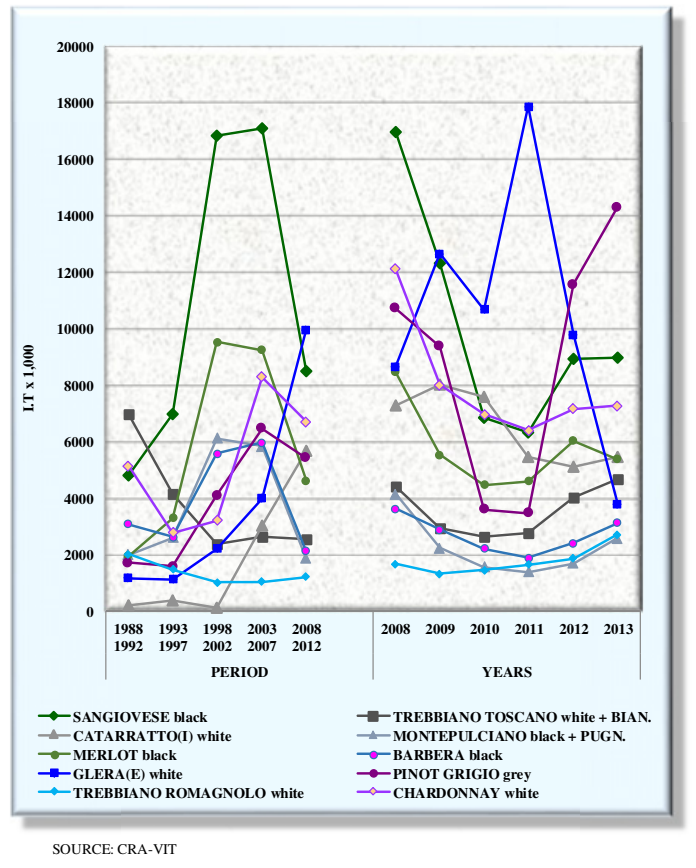

Figure 7. The evolution of graft cuttings of the top ten varieties in the Italian vineyard.

Therefore, we need to make a taxonomic clarification as to what is meant by variety, cultivar and biotype.

In our graphs, we have made corrections to statistical data, also to official data, that blatantly disagrees with the real situation. This is important for most Geographical Indication wines and for the new types of table wine indicating the variety.

The renewal of varieties is concentrated in a very short period and on the few varieties requested by the vinegrower, depending on the modal line of his interpretation and perception of the winemaking system.

In order to define the amounts of individual varieties in 2020, an algorithm has been created that considers 30 years of nursery production for each variety, mediated by: import-export, yield of graft cuttings in rootlings, number of plants/hectare and years of duration of the vineyard $^{6}$.

Figures 8 and 9 group together the wine grape varieties. The first, as percentages observed at the census; the second, as a percentage of grafts of the same variety planted in the field by nurserymen. The bar graphs can be superimposed to confirm how the nursery model interprets viticultural trends.

Thus, the concentration of just a few varieties in the Italian vineyard is confirmed, due both to market stimulation and to the abandoning of vineyards in many areas.

France has undergone a similar phenomenon in previous generations.

This entails the erosion of genetic variability, a common process in the main winegrowing regions.

\footnotetext{
${ }^{6}$ Due to their complexity, the unpublished results in this document are visible at http://www.devulpeetuva.com/ data_cap_8_7_1.html
}

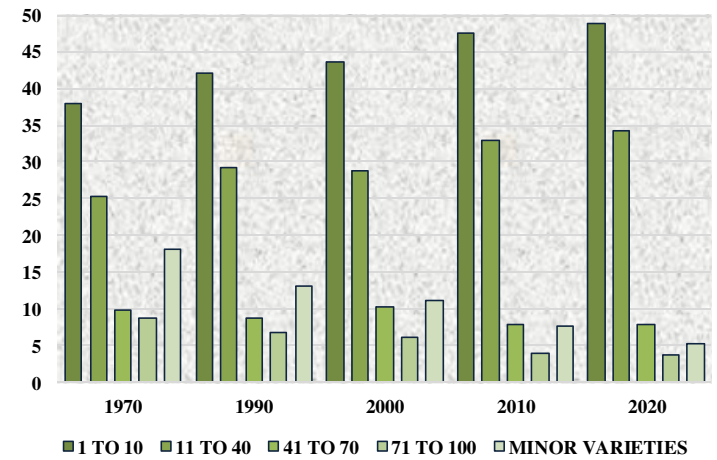

SOURCE: ISTAT

Figure 8. Percentage of surface area per group of varieties at the census.

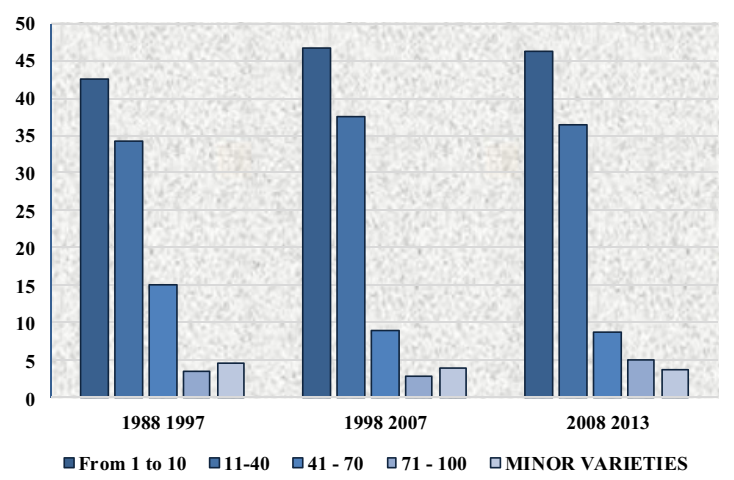

SOURCE: CRA-VIT

Figure 9. Percentage of graft cuttings per period.

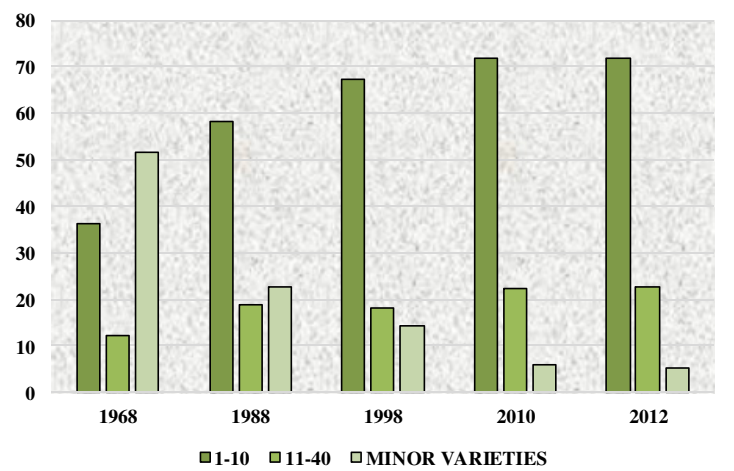

SOURCE: FranceAgriMer

Figure 10. France, percentage of surface area per group of varieties.

International grape varieties are relatively little present in the Italian vineyard (16.5\% of the surface area), of these, Pinot Grigio (incidentally, adopted and spread all over the world by Italians) has been widely affirmed, occupying in the future a similar surface area to Merlot, i.e. $4.4 \%$.

Another grape variety that has been present for a long time is Chardonnay, maintaining 3\% of the Italian vineyard. The other international varieties occupy less than $2 \%$. From this we can conclude that the Italian vineyard stands its own viticulture on native varieties. 


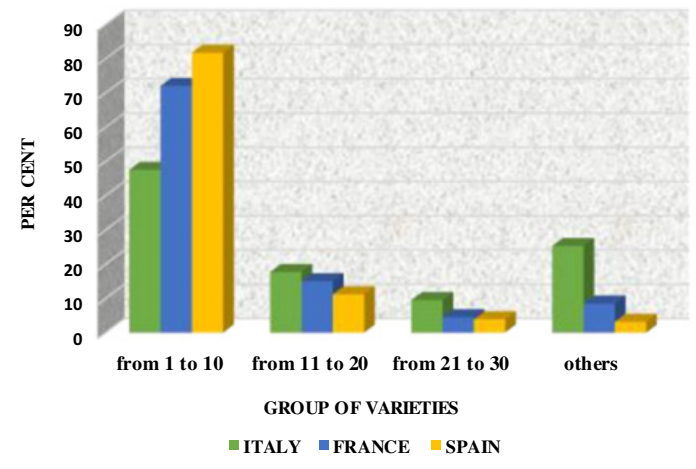

SOURCE: ISTAT, FranceAgriMer, others.

Figure 11. Comparison of the percentages of surface area per group of varieties, Italy, France and Spain in 2010.

Table 8. The top ten varieties (in percentages) in the three princeps winegrowing countries in 2010.

\begin{tabular}{|c|c|c|c|c|}
\hline VARIETY & IT & FR & SP & CULTURAL MODEL \\
\hline SANGIOVESE $\mathrm{b}$. & 11.5 & * & & Italian; Medicean \\
\hline TREBBIANO TOSCANO $\mathrm{w}$. & 5.6 & 10.2 & & Medicean; Cognac \\
\hline CATARRATTO (I) w. & 5.6 & & & Arabic-Norman \\
\hline MONTEPULCIANO $\mathrm{b}$. & 5.6 & & & Italian; Medicean \\
\hline MERLOT b. & 4.5 & 13.9 & * & Aquitaine international \\
\hline BARBERA $b$. & 3.3 & & & vitis montisferracentis \\
\hline GLERA (E) w. & 3.1 & & & Italian \\
\hline PINOT GRIGIO gr. & 2.8 & * & & Burgundy international \\
\hline TREBBIANO ROMAGNOLO w. & 2.5 & & & Italian \\
\hline CHARDONNAY w.* & 3.1 & 5.6 & * & Burgundy international \\
\hline GARNACHA b. (1) & $*$ & 10.8 & 7.2 & Provençal-Catalan \\
\hline SYRAH b. & * & 8.1 & 2.0 & Narbonne international \\
\hline CABERNET SAUVIGNON b. & * & 6.5 & 2.4 & Aquitaine international \\
\hline MAZUELO b.( 2)) & * & 5.3 & * & Provençal-Catalan \\
\hline CABERNET FRANC b. & * & 4.3 & & Aquitaine international \\
\hline PINOT NOIR b. & * & 3.7 & & Burgundy international \\
\hline GAMAY b. & & 3.5 & & Burgundy \\
\hline AIREN w. & & & 25.7 & Mozarabic \\
\hline TEMPRANILLO b. (3) & & & 21.2 & Aragonese \\
\hline BOBAL b. & & & 8.2 & Hispania Baetica \\
\hline MONASTRELL b. (4) & & $*$ & 6.0 & Provençal-Catalan \\
\hline VIURA w.(5) & & $*$ & 3.9 & Provençal-Catalan \\
\hline PARDINA w.(6) & & & 3.2 & Emerita Augusta \\
\hline ALICANTE H. BOUSCHET b. (7) & & $*$ & 2.0 & Recent French international \\
\hline $\begin{array}{l}\text { PERCENTAGE OF THE TOP } 10 \\
\text { VARIETIES }\end{array}$ & 47.5 & 71.9 & 81.7 & \\
\hline total ha $\times 1,000$ & 626.4 & 815.0 & 980.0 & \\
\hline $\begin{array}{l}\text { NOTE: * presence in the country. } \\
\text { (1) Grenache(2) Carignan Noir; (3) } \\
\text { Gibi; (6) Calagraño; (7) Garnacha }\end{array}$ & Tis & $A r$ & mó & 4) Mouryedere. (5) \\
\hline
\end{tabular}

The following Table 8 shows the presence of varieties in the three important winegrowing countries (princeps) in Europe.

The same varieties occupy the top positions in world viticulture and confirm that wine is a cultural heritage and that new lifestyles reward some of these to the detriment of others included in the top 30 positions.

They are varieties that have been consolidated through time in their respective cultivation areas, some are spreading (see Pinot Noir and Sauvignon), others such as Riesling Italico andRkatsiteli are decreasing as
Table 9. The top 30 wine grape varieties in the world.

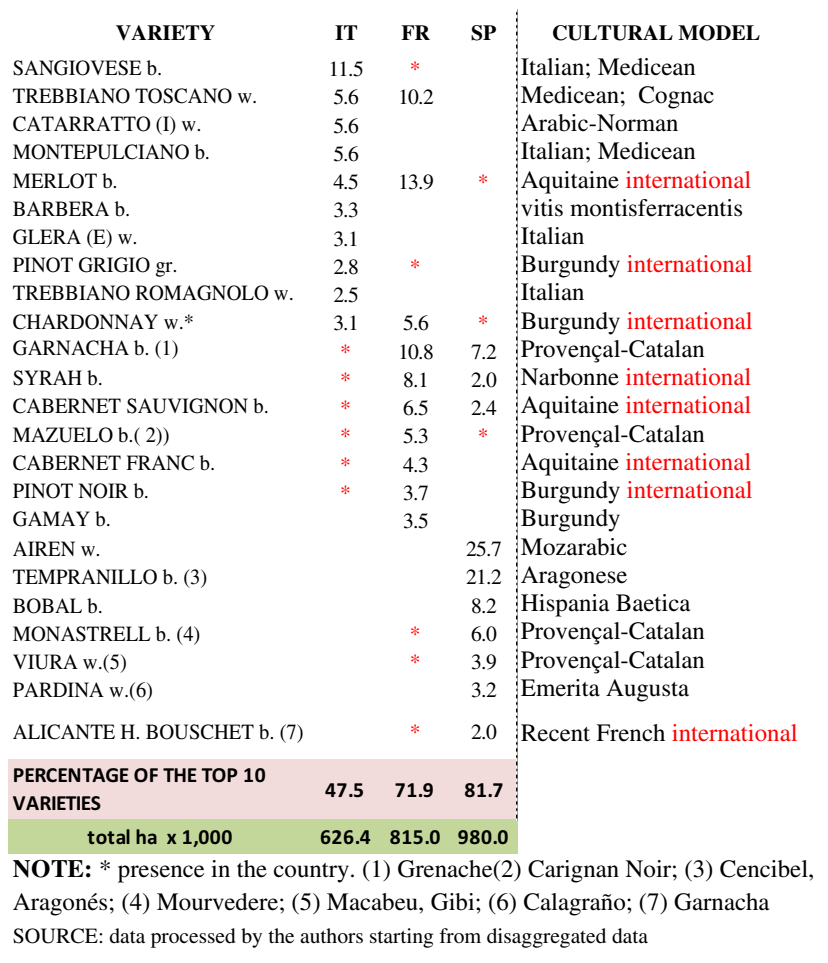

viticulture is abandoned as a consequence of socialpolitical changes ${ }^{7}$.

\subsection{The evolution of districts}

The evolution perceived by the nurseryman in 2020 will see viticulture consolidated into districts and especially in those where the vineyard-agroindustry-market system takes on a particular identity.

Marginal viticulture is being abandoned by generational change, the decrease and disappearance of personal consumption and diseconomies.

Typical varieties, the basis for the few important DOs, are taking hold in the districts: 30 DOs produce $65.8 \%$ of wines; a further 26 produce $13.4 \%$; whereas the plethora of Designations (another 302), fruit of political interests, compete for $20.7 \%$ of VQPRD wines.

The international (allochthonous) varieties mainly enter into the Geographical Indications, Pinot Grigio among them, valorized and promoted by Italy.

\subsubsection{Identity of the districts}

$>$ Heroic viticulture: Val d'Aosta (400 ha), Sondrio (800 ha) and Liguria (1,500 ha), difficult to cultivate, magnificent landscape, deep-rooted in tradition and tourism.

> Historic viticulture: based on strong values that manage to remunerate fairly the three segments of the production chain (vine-wine-market), in the regions

\footnotetext{
${ }^{7}$ To consult the full tables of varieties in viticulture in the different countries: http://www.devulpeetuva.com/
} data_cap_4.html 
Table 10. Synopsis of the Italian Vineyard.

\begin{tabular}{|c|c|c|c|c|c|c|c|c|c|c|c|c|}
\hline \multirow{3}{*}{ REGION } & \multicolumn{6}{|c|}{ HECTARES (in thousands) } & \multicolumn{3}{|c|}{$\mid \%$ OF HECTARES $\mid$} & \multicolumn{3}{|c|}{\begin{tabular}{|l|} 
\% VARIETIES ON THE \\
SURFACEAREA 2010
\end{tabular}} \\
\hline & \multicolumn{3}{|c|}{ total } & \multicolumn{3}{|c|}{ in district } & \multirow[t]{2}{*}{ DOs } & \multirow[t]{2}{*}{ GIs } & \multirow{2}{*}{$\begin{array}{c}\text { table } \\
\text { wines }\end{array}$} & \multicolumn{2}{|c|}{\begin{tabular}{|c|} 
SUKFACEAKEA \\
autochthonous
\end{tabular}} & \multirow{2}{*}{$\begin{array}{c}\text { allochtho } \\
\text { nous } \\
\text { foreign }\end{array}$} \\
\hline & 2000 & 2010 & 2020 & 2000 & 2010 & 2020 & & & & regional & Italian & \\
\hline VALLE D'AOSTA & 0.5 & 0.5 & 0.4 & & & & 50.0 & & 50.0 & 100.0 & & \\
\hline PIEDMONT & 52.6 & 46.6 & 40.0 & 43.1 & 33.7 & 30.0 & 81.1 & & 18.9 & 88.3 & 7.8 & 3.9 \\
\hline LIGURIA & 2.3 & 1.6 & 1.0 & & & & 55.6 & 4.1 & 40.3 & 100.0 & & \\
\hline LOMBARDY & 22.0 & 23.2 & 19.6 & 15.8 & 16.0 & 16.0 & 68.4 & 21.2 & 10.4 & 22.5 & 58.4 & 19.1 \\
\hline TRENTINO - A.A. & 13.8 & 15.7 & 15.0 & 11.7 & 13.1 & 13.1 & 84.7 & 10.2 & 5.1 & 32.5 & 12.1 & 55.4 \\
\hline VENETO & 73.6 & 77.9 & 75.0 & 57.1 & 62.6 & 64.0 & 48.3 & 43.6 & 8.1 & 54.8 & 10.1 & 35.1 \\
\hline FRIULI V.G. & 17.8 & 19.5 & 18.0 & 10.5 & 13.2 & 13.0 & 50.5 & 37.5 & 12.0 & 15.5 & 17.1 & 67.4 \\
\hline EMILIA - ROM. & 60.0 & 55.9 & 50.0 & 41.7 & 48.3 & 47.0 & 36.9 & 32.2 & 30.9 & 60.2 & 33.2 & 6.6 \\
\hline NORTH & 242.6 & 240.9 & 219.0 & 179.9 & 186.9 & 183.1 & 56.5 & 26.9 & 16.6 & 54.1 & 19.3 & 26.6 \\
\hline TUSCANY & 58.3 & 60.0 & 54.5 & 38.5 & 43.6 & 43.0 & 57.9 & 23.7 & 18.4 & 68.1 & 18.5 & 13.4 \\
\hline UMBRIA & 14.2 & 12.5 & 9.0 & 5.4 & 4.0 & 4.0 & 28.0 & 21.0 & 51.0 & 18.4 & 60.8 & 20.8 \\
\hline MARCHE & 19.8 & 16.9 & 13.0 & 10.2 & 8.3 & 6.0 & 40.2 & 23.8 & 36.0 & 17.3 & 78.5 & 4.2 \\
\hline LAZIO & 30.0 & 16.8 & 12.5 & 11.6 & 7.5 & 5.0 & 38.7 & 18.3 & 43.0 & 36.0 & 53.0 & 11.0 \\
\hline CENTRE & 122.3 & 106.2 & 89.0 & 65.7 & 63.4 & 58.0 & 47.4 & 21.6 & 31.0 & 48.9 & 38.8 & 12.3 \\
\hline ABRUZZO & 33.5 & 32.2 & 30.0 & 26.0 & 25.0 & 20.0 & 56.5 & 6.8 & 36.7 & 66.9 & 28.5 & 4.6 \\
\hline MOLISE & 5.9 & 5.2 & 4.5 & & & & 13.7 & 15.3 & 71.0 & & 90.4 & 9.6 \\
\hline CAMPANIA & 29.1 & 23.3 & 20.0 & 10.9 & 12.1 & 10.0 & 26.2 & 8.6 & 65.2 & 55.6 & 43.2 & 1.2 \\
\hline BASILICATA & 7.7 & 4.9 & 4.5 & & & & 16.6 & 10.0 & 73.4 & & 100.0 & \\
\hline CALABRIA & 13.4 & 9.9 & 8.0 & & & & 15.1 & 3.0 & 81.9 & 54.1 & 42.9 & 3.0 \\
\hline SARDINIA & 25.6 & 18.7 & 16.0 & & & & 31.2 & 8.2 & 60.6 & 61.7 & 26.3 & 12.0 \\
\hline SOUTH A & 115.2 & 94.2 & 83.0 & 36.9 & 37.1 & 30.0 & 34.2 & 8.2 & 57.6 & 54.2 & 40.7 & 5.1 \\
\hline APULIA & 85.0 & 82.8 & 79.0 & 69.6 & 70.4 & 70.0 & 7.9 & 24.8 & 67.3 & 50.5 & 45.5 & 4.0 \\
\hline SICILY & 110.9 & 104.1 & 97.0 & 91.7 & 84.1 & 80.0 & 3.8 & 46.1 & 50.1 & 72.2 & 6.8 & 21.0 \\
\hline SOUTH B & 195.9 & 186.9 & 176.0 & 161.3 & 154.5 & 150.0 & 5.2 & 36.4 & 58.4 & 61.2 & 25.8 & 13.0 \\
\hline ITALY & 676.0 & 628.2 & 567.0 & 443.8 & 441.9 & 421.1 & 37.2 & 26.3 & 36.5 & 82.8 & & 17.2 \\
\hline
\end{tabular}

of Piedmont (30,000 ha), Tuscany, with a network of districts (43,000 ha), Verona and Vicenza (33,000 ha) and Lambrusco wines in Emilia (20,000 ha).

$>$ Historic but diminishing viticulture: these are known historic areas that are imploding today, that have reduced the surface area of the districts from 2000 to 2010 as follows: Marche from 10,000 ha to 6,000 ha; Umbria, from 10,000 to 4,000 ha; Lazio from 12,000 to 5,000 ha and Sardinia from 10,000 to 5,000 ha; The latter region does not have any districts.

$>$ Innovative viticulture: with changes, sometimes complete disruption of the varieties, such as replacing native and/or Bordeaux varieties with base varieties for spumante or sparkling wines e.g. Glera from 8,000 to 27.000 ha, Chardonnay from 10,000 to 18,000 ha and fashionable wines such as Pinot Grigio from 7,000 to 25,000 ha. These changes concern the districts of eastern Veneto (31,000 ha), Friuli (13,000 ha), Trentino Alto Adige (13,000 ha) and Lombardy (16,000 ha).

> Viticulture trying to affirm itself: based on native varieties, but without the consolidated trade channels: Abruzzo (20,000 ha), Campania (10,000 ha) and southern Apulia (30,000).

> Viticulture aimed at varietal and/or general wines: Romagna (27,000 ha) Sicily (80,000 ha) and northern Apulia (40,000 ha).

The Italian regions of Apulia and Sicily share with Languedoc in France and Castilla-La Mancha in Spain a search for identity, hanging in the balance between general wines and alternative drinks such as beers, spirits and soft drinks, industrial products that cannot be classed as agricultural.

\section{Conclusion}

Wine is linked to fundamental aspects of ancient and modern culture and economy. It is a luxury good, a medicine and a tool for getting people together, wine was honoured in religious and funeral rites, but also in social relationships through the "symposium" (from the Greek syn "together" and pino "drink"), a banquet that was both a display of luxury and a ceremony of sharing between aristocratic groups, directly inspired by the eastern-Greek world.

Whereas in the past wine was predominantly the expression of social status, through time it has become one of the main economic resources of rural Italy.

According to the 2010 census, the Italian vineyard has an average of 1.7 hectares/farm, and only $2.7 \%$ of properties exceed 10 hectares, with a total of $34.6 \%$ of surface area.

Generational change favours the abandoning of micro farms, those under one hectare, which are important socially but not economically, particularly in central and southern Italy.

The abandonment of much of the wine-farming culture favours that agro-industry able to mobilise new technology, a reduction in costs and outsourcing for bulk wines without territorial identification.

The change in economic and social systems, the great burden of legislation and the economic crisis have reduced the appeal of the activity of winegrowing, causing to be abandoned even more, especially in marginal winegrowing areas. The latter can be identified with amateur vineyards, the heirs of a self-sufficient economy based mainly on native varieties. Hence the reduction of the precious genetic heritage, the erosion of culture and the farming culture.

The intervention of mass retail in the wine trade forces a simplification of the supply and favours the latter category (table wines indicating the variety).

This process, together with the ease of world trade, gives bargaining power to the commercial phase.

Despite the affirmation of territorial values, the only defence of the wine sector, the profitability of the sector is suffering.

The renewal of viticulture is not uniform in the different areas. Some, situated on sloping terrain, are subject to the simple replacement of missing vines, giving rise to perennial vineyards that boast high-quality wines.

The remaining hillside vineyards are renewed every thirty years, equal to $3.3 \%$ per year.

Viticulture in the plains, although the proud holder of geographical indications, can and does produce from 15 to 20 tonnes per hectare, making renewal necessary every 25 years, equal to a rate of $4 \%$ per year.

Some plain areas undergo changes of variety.

The areas that boast history, as well as cultural, farming and landscape identity and some World Heritage sites, remain anchored to tradition, producing VQPRD wines (Quality Wines Produced in Specified Regions).

The evolution of the Italian vineyard, seen by the privileged observer of national wine nursery production on the brink of 2020, sees a further important reduction in total surface area, the affirmation of few native varieties, the erosion of the ample genetic variability and poses a big question on the "resistance" of most of southern viticulture, today the producer of general wines.

For the critical reading to Javier Provedo (Spain) and Miguel Mercier (France). 
For the critical reading and translation to the journalist Matteo Marenghi, matteo.marenghi@yahoo.com.

\section{References}

[1] K. Anderson, N. Aryal, Which Winegrape Varieties are Grown Where? (Adelaide Press. Australia, 2013)

[2] M. Boselli, G. Tempesta, M. Fiorilo, Aree geografiche e distretti di successo. VQ, 3: 71-73 (2013)

[3] M. Boselli, G. Tempesta, M. Fiorilo, La diffusione della viticoltura delle eccellenze nelle aree di protezione in Italia. 35th World Congress of Vine and Wine, 18-22 june, Izmir (Turkey), oral presentation (2012)

[4] M. Boselli, G. Tempesta, M. Fiorilo, Architetti fra i filari. VQ, 5: 28-32 (2011)

[5] J. Clavel, Mondialisation des Vins, (Ed. Féret, 2008)
[6] J. Robinson, J. Harding, J. Vouillamoz, Wine Grape, (Allen Lane an imprint of Penguin Books Ltd, London)

[7] G. Tempesta, M. Fiorilo, M. Marenghi, Vigneto Italia: Stato attuale, movimenti e tendenze nel Paese del Vino. (Ed Wine Pass, Alba, 2014)

[8] G. Tempesta, M. Fiorilo, M. Boselli M., Vitigni autoctoni e di antica coltivazione come marcatori della tipicità ed identità del territorio. $31^{\circ} \mathrm{C}$ ongresso Mondiale della Vigna e del Vino, 15-20 giugno. Verona (2008)

[9] G. Tempesta, M. Fiorilo, D. Begalli, M. Boselli, Sistema Vitivicolo italiano come modello evolutivo. XXXth World Congress of Vine and Wine. Budapest, 10-16 june. http://www.oiv2007.hu/ documents/law_economics317_sistema_vitivin icolo_italiano_come_modello_evolutivo.pdf (2007) 